\title{
PREGNANCY-BLOCK IN THE MEADOW VOLE, MICROTUS PENNSYLVANICUS
}

\author{
F. V. GLULOW AND P. E. LANGFORD \\ Department of Biology, Laurentian University, Sudbury, Ontario, Canada
}

(Received 30th Fune 1970, revised 12th October 1970)

\begin{abstract}
Summary. In meadow voles, Microtus pennsylvanicus, bred from stock trapped in the wild and maintained under laboratory conditions, a reduction in the incidence of pregnancy (from $60 \%$ to $20 \%$ ) follows exposure of recently inseminated females to strange males of the same species.
\end{abstract}

Bruce (1959) first showed that pregnancy is interrupted if recently inseminated female albino mice, Mus musculus, are exposed to males other than those with which they have mated. In mice, this 'Bruce effect' is known to be due to failure of the fertilized ova to implant in the uterus (Bruce, 1960). Pheromones have been implicated in the mechanism of blockage (Bruce \& Parrott, 1960). Male-induced blockage of pregnancy has also been reported in the deer mouse, Peromyscus maniculatus (Eleftheriou, Bronson \& Zarrow, 1962; Bronson \& Eleftheriou, 1963; Bronson, Eleftheriou \& Garick, 1964) and the field vole, Microtus agrestis (Glulow \& Glarke, 1968). An experiment was performed with the meadow vole, Microtus pennsylvanicus, to see if the same phenomenon occurs in this ubiquitous North American microtine rodent.

Mature virgin voles, bred in this department from stock trapped in the wild, were used in the experiment. From weaning at 20 days of age, the animals were individually housed in plastic cages $(28.5 \times 17.5 \times 12.5 \mathrm{~cm})$ with ample water, hay for cover, cotton for bedding, unrestricted oats and carrot twice a week. The floors of the cages were covered with sawdust. The animals were maintained under controlled conditions of light (18 hr light/6 hr dark) and temperature $\left(25 \pm 2^{\circ} \mathrm{C}\right)$. Vaginal smears were taken from the females before pairing and those which had cornified/nucleated smears were immediately used in the experiment. Experience indicated that females with leucocytic smears were unlikely to copulate. Such females were examined twice daily until the appearance of cornified or nucleated cells in the smear and they were then introduced to the experiment. During the time spent with the males and for the whole of the gestation period, vaginal smears were taken from the females twice a day. Males and females were paired in new clean cages with cover (hay and cotton) omitted so as to allow observations to be made of behaviour. The animals were kept together for 3 days. The criterion used to judge that coitus had occurred was the observation of spermatozoa in a vaginal smear.

Forty inseminated females were distributed at random into two treatment 
groups. The females of one group were kept with their stud males in the original cages for a further $24 \mathrm{hr}$ (after the sawdust and food in the cages had been changed). The females of the other group were similarly treated except that strange males were substituted for the studs for the 24-hr period.

After pairing with the males, all females were isolated in large plastic holding cages $(46.5 \times 20.5 \times 14.0 \mathrm{~cm})$ and were observed for 3 weeks (i.e. a period longer than the gestation period). Any litters produced were noted.

When the females and stud males were caged together there was frequently some initial fighting which ceased after the first successful copulation. Fighting between females and strange males was common and sometimes persisted intermittently for $24 \mathrm{hr}$. Of the twenty females exposed only to the stud males, twelve produced litters. Of those exposed to strange males, only four produced litters. This difference in the number producing litters is significant $\left(\chi_{1}^{2}=5 \cdot 1\right.$, $P<0.05)$. Of the four females producing litters after the second treatment, three were known to have mated with the strange males.

Vaginal smears taken before and after mating and blocking were examined. The usual consequence of coitus was an invasion by leucocytes of a previously cornified or nucleated cell smear pattern. In cases where blockage occurred, the leucocytic invasion regressed and a cornified/nucleated cell smear reappeared within $72 \mathrm{hr}$ of the start of exposure to the strange male.

The leucocytic invasions seen in the vaginal smears after mating and their retreat after exposure of the females to strange males are similar to those seen in $M$. agrestis, an induced ovulator (Breed, 1967), under similar circumstances (Clulow \& Glarke, 1968). This observation agrees with other work which shows that $M$. pennsylvanicus is also an induced ovulator (Clulow \& Mallory, 1970).

The data show that the pregnancy rate is depressed in females exposed to strange males 3 days or less after coitus. This parallels what has been seen in other species (Bruce, 1959; Bronson \& Eleftheriou, 1963; Clulow \& Glarke, 1968). The low pregnancy rate $(60 \%)$ in the females without a block may have been due to experimental procedures as it is known (Eleftheriou et al., 1962) that other environmental factors, such as disturbance, are effective in blocking pregnancy.

The suggestion that pregnancy-block may play a part in the regulation of population levels of mammals in the wild (Ghipman, Holt \& Fox, 1966; Glulow \& Clarke, 1968) is being examined in this laboratory.

We thank Mrs T. E. Kreke for her assistance. This work was supported by the National Research Council of Ganada, grant A-5070.

\section{REFERENCES}

Breed, W. G. (1967) Ovulation in the genus Microtus. Nature, Lond. 214, 826.

Bronson, F. H. \& Eleftheriou, B. E. (1963) Influence of strange males on implantation in the deermouse. Gen. E compar. Endocr. 3, 515.

Bronson, F. H., Eleftheriou, B. E. \& Garick, E. I. (1964) Effects of intra- and inter-specific social stimulation on implantation in deermice. $\mathcal{F}$. Reprod. Fert. 8, 23.

BRUCE, H. M. (1959) An exteroceptive block to pregnancy in the mouse. Nature, Lond. 184, 105.

BRUCE, H. M. (1960) A block to pregnancy in the mouse caused by the proximity of strange males. 7. Reprod. Fert. 1, 96. 
Bruce, H. M. \& PARrott, D. M. V. (1960) Role of olfactory sense in pregnancy block by strange males. Science, N.Y. 131, 1526.

Chipman, R. K., Holt, J. A. \& Fox, K.A. (1966) Pregnancy failure in laboratory mice after multiple short-term exposure to strange males. Nature, Lond. 210, 653.

Glulow, F. V. \& Glarke, J. R. (1968) Pregnancy-block in Microtus agrestis an induced ovulator. Nature, Lond. 219, 511.

Glulow, F. V. \& Mallory, F. F. (1970) Oestrus and induced ovulation in the meadow vole, Microtus pennsylvanicus. F. Reprod. Fert. 23, 341.

Eleftheriou, B. E., Bronson, F. H. \& Zarrow, M. X. (1962) Interaction of olfactory and other environmental stimuli on implantation in the deermouse. Science, N.Y. 137, 764. 